\title{
PENERAPAN BLUE OCEAN STRATEGY PADA TRANS STUDIO BALI PT. CHAIRUL TANJUNG CORPORA
}

\author{
THE IMPLEMENTATION OF BLUE OCEAN STRATEGY IN \\ TRANS STUDIO BALI PT. CHAIRUL TANJUNG CORPORA
}

\author{
Meyta Nurul Aini" ${ }^{* 1}$, Lina Auliana*), dan Muhammad Rizal ${ }^{*}$ \\ *) Departemen Administrasi Bisnis, Fakultas Ilmu Sosial dan Ilmu Politik, Universitas Padjadjaran \\ Jl. Raya Bandung Sumedang KM.21, Hegarmanah, Jatinangor, Sumedang 45363 Indonesia
}

\begin{abstract}
This study aimed to evaluate BOS implementation, further with Covid19 existence, particularly to examine BOS implementation showed three good characteristics or not, and company's response to Covid-19, concerning adoption barriers indicator. This study used qualitative method, employed in-depth interviews and questionnaires data collection to consumers and nonconsumers taken in October 2020. Four Actions Framework, ERRC Grid Scheme, and former studies brainstorming were used to analyze industrial competition factors, which were then analyzed using orthogonal varimax rotation factor to generate value curve. The results indicated company's value curve did not meet BOS's good characteristics, as reflected by high-value curve in first major competition factors, as well as lack of conditions adjustment during Covid-19. The managerial implication implied that it raised further questions whether market share and company profitability reflected investment or offered excess supply, as well as it urged the company to consider adjusting to conditions quickly.
\end{abstract}

Keywords: Bali indoor theme park, blue ocean strategy, four action framework, ERRC grid scheme, varimax orthogonal factor rotation

\begin{abstract}
Abstrak: Penelitian ini bertujuan mengevaluasi penerapan BOS terlebih dengan keberadaan Covid-19, yakni untuk melihat penerapan BOS tersebut menunjukkan tiga ciri baik atau tidak, dan melihat respon perusahaan terkait pandemi Covid-19 dengan memperhatikan indikator hambatan pengadopsian. Penelitian ini menggunakan metode kualitatif dengan pengambilan data menggunakan wawancara mendalam dan kuesioner kepada konsumen dan nonkonsumen yang diambil pada Oktober 2020. Four Actions Framework, ERRC Grid Scheme, serta brainstorming penelitian terdahulu digunakan untuk menganalisis faktor kompetisi industri, yang selanjutnya dianalisis menggunakan rotasi faktor varimax orthogonal untuk membuat kurva nilai perusahaan. Hasil penelitian ini menunjukkan kurva nilai perusahaan tidak memenuhi ciri BOS yang baik, tercermin oleh kurva bernilai tinggi pada seluruh faktor kompetisi utama pertama, serta kurangnya penyesuaian kondisi saat pandemi Covid-19. Implikasi manajerial dari penelitian ini yakni menimbulkan pertanyaan lanjutan apakah pangsa pasar dan profitabilitas perusahaan mencerminkan investasi atau perusahaan justru menawarkan kelebihan pasokan, serta perusahaan perlu memperhatikan penyesuaian kondisi dengan cepat berkenaan Covid-19.
\end{abstract}

Kata kunci: Bali indoor theme park, blue ocean strategy, four action framework, ERRC grid scheme, rotasi faktor varimax orthogonal

\footnotetext{
${ }^{1}$ Corresponding author:

Email: meyta17001@mail.unpad.ac.id
} 


\section{PENDAHULUAN}

Pariwisata nasional berkontribusi nyata melalui devisa negara, pendapatan asli daerah, serta terhadap preferensi investor dalam menanamkan modalnya di Indonesia. Buku Rencana Strategis Kementerian Pariwisata Tahun 2018-2019 menyatakan bahwa pariwisata nasional pada tahun 2017 berkontribusi terhadap PDB Nasional sebesar 5\%, dengan devisa sejumlah Rp 200 triliun dan menyerap 12,28 juta tenaga kerja. Kontribusi tersebut menjadi dasar penetapan pariwisata sebagai salah satu leading sector pembangunan Indonesia. Sejalan dengan itu, perusahaan berlomba membangun usaha di sektor pariwisata sejalan pertumbuhan wisatawan yang menjanjikan. Lebih lanjut, meningkatnya permintaan di sektor ini menarik perhatian investor. Data dari Badan Koordinasi Penanaman Modal (BKPM) menunjukkan pertumbuhan investasi di sektor pariwisata (Gambar $1)$.

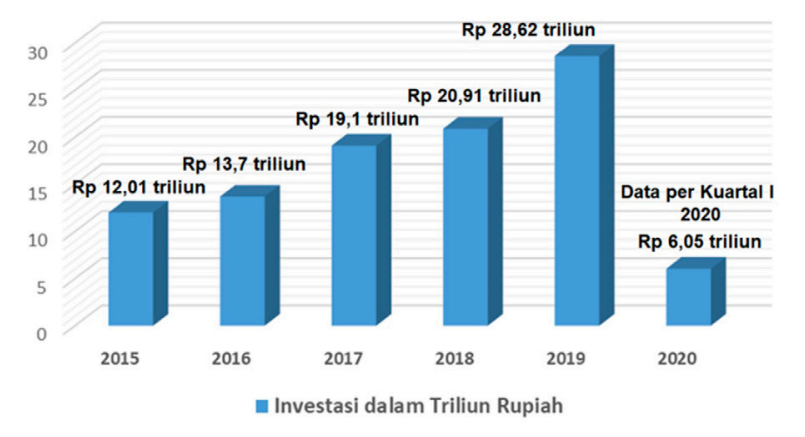

Gambar 1. Investasi Sektor Pariwisata (BKPM, 2020)

Menurut Tribe dalam Fajarin (2020), kekuatan pasar dalam pariwisata diatur dengan prinsip yang sama seperti pasar lain, yaitu harga ditentukan dari adanya interaksi antara permintaan dan penawaran. Setiap faktor yang memengaruhi permintaan dan atau penawaran dari produk pariwisata menyebabkan ada atau tidaknya keseimbangan dalam pasar. Maka, keseimbangan pasar bergantung pada elastisitas permintaan dan penawaran produk pariwisata. Hal lain yang tidak bisa dipungkiri yakni persaingan usaha sektor ini semakin ketat. Diperlukan strategi untuk memenangkan kompetisi serta jika perlu menjamah pangsa pasar yang belum terjamah oleh pesaing. Strategi yang dimaksud yakni Blue Ocean Strategy (BOS). BOS menggambarkan industri yang tidak eksis saat ini yakni untuk menjamah pangsa pasar yang belum terjamah oleh pesaing dimana menekan pada inovasi nilai serta capaian biaya rendah pada penawarannya. BOS menuntun pelaku usaha agar dapat menghindari pasar yang sudah keruh dan padat dengan menciptakan permintaan baru yang berpotensi sehingga menjadikan persaingan tidak relevan.

PT. Chairul Tanjung Corpora atau CT Corp merupakan kelompok perusahaan konsumen terbesar di Indonesia, berkembang pesat termasuk di sektor pariwisata. Melalui melalui unit usahanya PT. Alfa Retailindo, CT Corp menunjukkan performa baik terkhusus sektor ritel, pariwisata, dan properti, ditunjukan oleh keberhasilannya menjalin kerjasama senilai USD 275 juta dolar dengan International Finance Corporation (IFC) pada 2019 silam. Kerjasama ini bertujuan memaksimalkan pengembangan sektor swasta di Indonesia, dalam hal ini CT Corp dipertimbangkan mampu mendukung terciptanya lapangan kerja ketiga sektor tersebut. Pengembangan tiga sektor tersebut dilakukan CT Corp dalam kompleks hiburan terpadu mencakup usaha ritel, pariwisata, dan properti. Produk pariwisata unggulannya adalah jaringan taman bermain Trans Studio yakni taman bermain dalam ruangan (indoor theme park) terbesar di Indonesia, dimana Trans Studio menjadi tourist attraction icon kompleks tersebut. Terdapat empat Trans Studio yang sebelumnya dibangun di Makassar, Bandung, Cibubur, dan Bali. Trans Studio Bali merupakan indoor theme park terbaru CT Corp, diresmikan Desember 2019 silam yang merupakan indoor theme park pertama di Bali serta diklaim sebagai yang terbaik se-Asia Tenggara. Dengan menjadikannya yang pertama di Bali, CT Corp menciptakan pangsa pasar baru untuk produk indoor theme park di pasar yang belum terjamah pesaing, dengan tidak hanya menargetkan wisatawan nusantara, tetapi juga berfokus pada wisatawan mancanegara.

Berdasarkan data dari Badan Pusat Statistik, Bali tercatat dengan jumlah wisatawan mancanegara terbanyak seIndonesia, per akhir 2019 terdapat 5.710 .467 orang wisatawan mancanegara berdasarkan pintu masuk bandara dimana selalu meningkat setiap tahunnya, serta terdapat 6.275 .210 orang wisatawan mancanegara berdasarkan akumulasi semua pintu masuk. Namun, pada tahun 2020, pandemi Covid-19 menyebar cepat dan pertama kali ditemukan di Indonesia pada Maret 2020. Pandemi Covid-19 menghantam keras ekonomi dan industri pariwisata Bali. Pemerintah daerah Bali menyatakan Bali berada dalam kondisi dimana semua layanan mengalami kelebihan pasokan karena tidak ada wisatawan akibat pembatasan secara fisik. Data Gabungan Industri Pariwisata Indonesia (GIPI) Bali 
melalui The Jakarta Post (2020) mencatat potensi kerugian pariwisata di Bali mencapai \$ 628,367 dolar Amerika Serikat atau sekitar lebih dari Rp9 miliar per bulan. Selain itu, berdasarkan survei dari Yelp, consumer interest untuk industri theme park mengalami penurunan signifikan (Gambar 2). Tentunya hal ini berpengaruh juga pada aktivitas bisnis Trans Studio Bali.

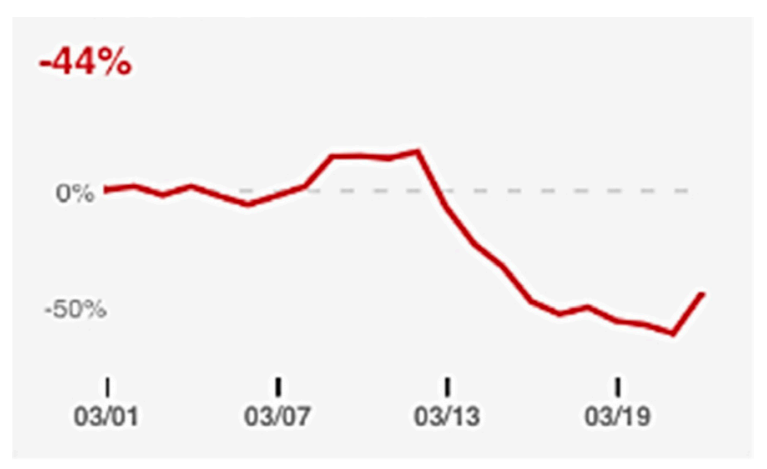

Gambar 2. Consumer Interest Saat Covid-19 (Yelp dalam Matt Southern, 2020)

Berdasarkan wawancara pra penelitian dengan Head of Corporate Development CT Corp (Hospitality \& Entertainment Group) terkait strategi pada Trans Studio Bali, perusahaan menunjukkan penerapan Blue Ocean Strategy (BOS) di hampir keseluruhan indikator berdasarkan dimensi yang ada. Namun, terdapat indikator-indikator pada tiga dimensi berbeda yang mana perusahaan tidak menunjukkan penerapannya (Tabel 1).

Philippe Zgheib (2017) menyatakan bahwa konsep dari ocean water strategy sebagian besar tidak diketahui. Dalam 25 tahun, fokus utama perusahaanperusahaan dalam pemikiran strategis adalah pada strategi bersaing, dan kompetisi berakar di pusat pola strateginya. Sementara itu, Andrew Burke, Andre van Stel, dan Roy Thurik (2009) dalam penelitiannya yang berjudul Blue Ocean compared to competitive strategy: Theory and Evidence, menunjukkan bahwa blue ocean strategy sukses diaplikasikan pada corporate level dibandingkan pengaplikasian strategi bersaing. Menurut Kim dan Mauborgne (2005), Blue Ocean Strategy (BOS) menggambarkan industri yang tidak eksis pada saat ini. Sementara, pada red ocean, batasbatas industri ditentukan dan diterima, dan aturan persaingan permainan dipahami dengan baik (Aithal, 2016). BOS merupakan market space yang belum diketahui dan belum tersentuh, dimana menciptakan permintaan baru untuk pertama kalinya. Bagaimana perusahaan mengalihkan diri dari persaingan red ocean menunju pada blue ocean yang membuat kompetisi menjadi tidak relevan lagi. Salah satu konsep dasar dari BOS adalah inovasi nilai. Inovasi nilai tidak selalu berupa inovasi teknologi, tetapi berupa inovasi untuk peningkatan keuntungan konsumen yang disesuaikan dengan harga jual dan biaya.

Terdapat beberapa penelitian yang menyinggung hal yang dibahas dalam penelitian ini antara lain penelitian dari Rawabdeh et al. (2012) berjudul Blue Ocean Strategy as a Tool for Improving a Company's Marketing Function: The case of Jordan, penelitian tersebut mengusulkan penerapan BOS sebagai alat untuk meningkatkan fungsi pemasaran dalam sebuah perusahaan manufaktur cokelat di Yordania dengan hasil utama bahwa perusahaan berhasil mengidentifikasi sejumlah produk baru yang dapat mengembangkan pasar baru sendiri untuknya (blue ocean markets). Sementara itu, penelitian dari Sitinjak et al. (2018) berjudul ICanStudioLive use of Blue Ocean Marketing Strategy for Value Differentiation, bertujuan mengetahui apakah ICanStudioLive menerapkan BOS secara sadar atau tidak, dengan hasil penelitian menunjukkan ICanStudioLive mempraktikkan strategi diferensiasi mirip dengan BOS. Perbedaan penelitian terdahulu dengan penelitian ini terletak pada tujuan akhir dari BOS yang sebelumnya sudah diterapkan perusahaan.

Konsep kunci BOS terletak pada inovasi nilai, kepemimpinan tipping point, dan mencakup tiga elemen proses yang adil. Proses yang adil merujuk pada keterlibatan seluruh karyawan dalam eksekusi strategi, sementara kepemimpinan tipping point berfokus pada sentralisasi ide, untuk mengurangi tindakan tidak proposional. Jika berkaca dari ukuran perusahaan, perusahaan sulit menerapkan keduanya sekaligus. Sementara itu, penerapan BOS yang baik yakni memenuhi tiga ciri meliputi fokus, divergensi, dan mempunyai motto/tagline memikat yang berbicara kepada pasar. Sehingga dalam hal tersebut perlu diketahui lebih lanjut, dimana penelitian ini bersifat evaluasi terhadap penerapan BOS pada Trans Studio Bali terlebih dengan adanya pandemi Covid-19 yang tidak terduga. Hal ini untuk melihat penerapan teori BOS itu sendiri, dimana penerapan indikatornya disesuaikan dengan kondisi perusahaan dengan tidak menerapkan beberapa indikator yang ada, dapat menunjukkan tiga ciri baik BOS atau tidak, serta melihat 
respon perusahaan terhadap pandemi Covid-19 dengan memperhatikan indikator hambatan pengadopsian BOS dalam mewujudkan ide bisnis. Sehingga, pertanyaan penelitian dapat teridentifikasi sebagai berikut: Bagaimana penerapan BOS pada Trans Studio Bali?

\section{METODE PENELITIAN}

Penelitian ini menggunakan metode kualitatif dengan jenis penelitian in-depth interview berdasarkan studi kasus penerapan Blue Ocean Strategy (BOS) pada Trans Studio Bali. Pendekatan yang dilakukan adalah survei dengan teknik wawancara, observasi, dan kuesioner terhadap responden mencakup karyawan perusahaan, konsumen dan nonkonsumen, ditentukan dengan purposive sampling yang diambil pada Oktober 2020. Teknik analisis meliputi data reduksi, data display, dan conclusion drawimg/verification. Didukung dengan penggunaan kerangka kerja Four Actions Framework dan alat analisis ERRC Grid Scheme untuk membuat kurva nilai perusahaan pada kanvas strategi yang diinterpretasi sesuai hasil analisis rotasi faktor orthogonal dengan metode varimax berdasarkan kuesioner terhadap konsumen dan nonkonsumen Trans Studio Bali.

Tabel 1. Penerapan indikator blue ocean strategy pada Trans Studio Bali

\begin{tabular}{|c|c|c|}
\hline Dimensi & Indikator & Status Penerapan \\
\hline \multirow[t]{2}{*}{ Inovasi Nilai } & Biaya & $\sqrt{ }$ \\
\hline & Nilai tambah & $\sqrt{ }$ \\
\hline \multirow{6}{*}{$\begin{array}{l}\text { Merekonstruksi batasan- } \\
\text { batasan pasar }\end{array}$} & Mencermati industri alternatif & $\sqrt{ }$ \\
\hline & Mencermati kelompok-kelompok strategis dalam industri & $\sqrt{ }$ \\
\hline & Mencermati rantai pembeli & $\sqrt{ }$ \\
\hline & Mencermati penawaran produk dan jasa pelengkap & $\sqrt{ }$ \\
\hline & Mencermati daya tarik emosional atau fungsional bagi pembeli & $\sqrt{ }$ \\
\hline & Mencermati waktu & $\sqrt{ }$ \\
\hline \multirow{4}{*}{$\begin{array}{l}\text { Fokus pada gambaran besar } \\
\text { bukan angka }\end{array}$} & Kebangkitan visual & $\sqrt{ }$ \\
\hline & Eksplorasi visual & $\sqrt{ }$ \\
\hline & Pameran strategi visual & $\sqrt{ }$ \\
\hline & Komunikasi visual & $\mathrm{X}$ \\
\hline \multirow{3}{*}{$\begin{array}{l}\text { Menjangkau melampaui } \\
\text { permintaan yang ada }\end{array}$} & Mencermati nonkonsumen tingkat pertama & $\sqrt{ }$ \\
\hline & Mencermati nonkonsumen tingkat kedua & $\mathrm{X}$ \\
\hline & Mencermati nonkonsumen tingkat ketiga & $\sqrt{ }$ \\
\hline \multirow{4}{*}{$\begin{array}{l}\text { Melakukan rangkaian } \\
\text { strategis secara benar }\end{array}$} & Utilitas bagi konsumen & $\sqrt{ }$ \\
\hline & Harga & $\sqrt{ }$ \\
\hline & Biaya & $\sqrt{ }$ \\
\hline & Pengadopsian & $\sqrt{ }$ \\
\hline \multirow{4}{*}{$\begin{array}{l}\text { Mengatasi rintangan- } \\
\text { rintangan utama organisasi }\end{array}$} & Rintangan kognitif & $\sqrt{ }$ \\
\hline & Rintangan sumber daya & $\sqrt{ }$ \\
\hline & Rintangan motivasional & $\sqrt{ }$ \\
\hline & Rintangan politik & $\sqrt{ }$ \\
\hline \multirow{3}{*}{$\begin{array}{l}\text { Melakukan ekseksui } \\
\text { dengan proses yang adil }\end{array}$} & Elemen engagement & $\mathrm{X}$ \\
\hline & Elemen explanation & $\mathrm{X}$ \\
\hline & Elemen expectation clarity & $\sqrt{ }$ \\
\hline
\end{tabular}


Four Actions Framework dapat digunakan untuk mendobrak dilemma antara diferensiasi dan biaya rendah, terdapat empat langkah dan pertanyaan kunci untuk menantang logika strategi dan model bisnis sebuah industri (Kim dan Mauborgne, 2005), yakni faktor apa saja yang harus dihapuskan, dikurangi, ditingkatkan, diciptakan. Kerangka kerja ini dikembangkan untuk merekonstruksi elemen-elemen nilai pembeli dalam membuat kurva nilai baru. Sedangkan, ERRC Grid Scheme merupakan alat analisis pelengkap dari Four Actions Framework. ERRC Grid Scheme meliputi Eliminate - Reduce - Raise - Create. Skema ini mendorong perusahaan untuk tidak hanya menanyakan empat pertanyaan, tetapi juga bertindak berdasarkan keempat pertanyaan itu untuk menciptakan suatu kurva nilai pada kanvas strategi. Kanvas strategi itu sendiri adalah kerangka aksi diagnosis untuk membangun BOS yang baik, berfungsi merangkum situasi pasar yang sudah dikenal serta mendorong kegiatan dengan mereorientasi fokus dari kompetitor ke industri alternatif dan dari konsumen ke nonkonsumen. Sementara itu, kurva nilai merupakan kompenen dasar dari kanvas strategi berupa penggambaran grafis kinerja relatif perusahaan mengenai faktor kompetisi industri. Bila kurva nilai memenuhi tiga ciri yaitu fokus, divergensi, dan mempunyai motto/tagline memikat yang berbicara kepada pasar, mendefinisikan BOS yang baik. Tagline itu sendiri merupakan bagian dari komponen identitas merek yang biasanya dirumuskan secara mendalam untuk mengomunikasikan pemosisian merek (Sadat dalam Astuti, 2018). Bila kurva nilai suatu perusahaan bertemu kurva nilai pesaingnya, perusahaan terperangkap dalam kompetisi red ocean. Bila kurva nilai menunjukkan tingkat nilai tinggi dalam semua faktor, maka harus dipertanyakan apakah pangsa pasar dan profitabilitas perusahaan mencerminkan investasi. Jika tidak, perusahaan mungkin memberikan pasokan berlebih dan memberikan penawaran terlalu banyak. Jika kurva nilai suatu perusahaan terlihat tanpa pola atau alasan yang jelas, dimana penawaran bisa digambarkan naik-turun-naik-turun, maka menunjukkan perusahaan tidak mempunyai strategi yang koheren.

Tahapan pertama penelitian yakni menghimpun informasi mengenai kondisi umum Trans Studio Bali serta penerapan BOS dengan pihak-pihak yang bekerja di CT Corp (Hospitality \& Entertainment Group) terkhusus mengenai Trans Studio Bali. Tahapan selanjutnya menganalisis berdasar indikator pada dimensi BOS termasuk tiga ciri baiknya menggunakan Four Actions Framework dan ERRC Grid Scheme untuk mengidentifikasi faktor kompetisi. Hal ini juga dilakukan dengan membandingkan penelitianpenelitian terdahulu mengenai industri theme park.

Tahapan selanjutnya menguji dan menganalisis faktor yang telah diidentifikasi melalui kuesioner kepada 37 responden. Menurut Alwi (2012), suatu teorema variabel tunggal atau univariant, yaitu teorema limit sentral, yang menyatakan statistik rata-rata mempunyai distribusi normal untuk ukuran sampel mendekati tak berhingga. Akan tetapi dalam praktek, teorema limit sentral dapat diterapkan untuk ukuran sampel minimal 30. Sugiyono dalam Damayanthi (2016) menyatakan, ukuran sampel yang layak adalah antara 30 sampai 500 orang. Selain itu, Nurudin et al. (2014) mengemukakan, pada saat ukuran sampel 30, sampel yang berdistribusi normal meningkat menjadi sebanyak 87\%. Artinya, ukuran sampel 30 telah menyebar normal. Sehingga pemilihan 37 responden dalam penelitian ini cukup mewakili.

Hasil identifikasi selanjutnya dianalisis untuk menentukan faktor-faktor mana saja yang menjadi komponen utama (principle component) satu dan dua. Analisis faktor adalah pendekatan statistik yang dapat digunakan untuk menganalisis hubungan (interrelationship) sejumlah (besar) variabel dan untuk menjelaskan dimensi-dimensi (disebut faktor) apakah yang melandasi variabel-variabel tersebut (Simamora, 2005). Analisis faktor digunakan dalam menempatkan faktor kompetisi pada sumbu horizontal kanvas strategi yang mana tidak memerlukan alat pengujian korelasi variabel Kaiser-Meyer-Olkin Measure of Sampling Adequacy (KMO-MSA) dan Barlett's Test. Hal ini dikarenakan, pengujian ini mengharuskan adanya korelasi yang signifikan diantara paling sedikit beberapa variabel (faktor kompetisi) (Rahardjo, 2013). Analisis faktor pada penelitian ini menggunakan metode rotasi orthogonal, yaitu metode varimax. Metode rotasi ini berupaya memaksimalkan faktor pembobot dan mengakibatkan variabel asal hanya akan mempunyai korelasi yang tinggi dan kuat dengan faktor tertentu saja (korelasinya mendekati 1) dan memiliki korelasi yang lemah dengan faktor yang lainnya (korelasinya mendekati 0) (Himayati et al. 2020).

Analisis tersebut bertujuan menggambarkan kurva nilai faktor kompetisi perusahaan dengan theme park terkenal dan theme park lainnya di Bali dalam kanvas strategi menggunakan nilai rataan untuk mengetahui penerapan BOS pada Trans Studio Bali menunjukkan 
tiga ciri baik atau tidak, serta bagaimana respon perusahaan terkait kondisi pandemi Covid-19 dengan memperhatikan indikator hambatan pengadopsian dalam mewujudkan ide bisnis.

Dari hasil tersebut, dapat diketahui jika penerapan BOS yang disesuaikan dengan kondisi perusahaan dimana tidak menerapkan beberapa indikator yang ada, ternyata menunjukkan tiga ciri BOS yang baik, maka dapat disimpulkan bahwa teori BOS dalam penerapan indikator pada dimensinya dapat disesuaikan dengan kondisi perusahaan terkhusus untuk studi kasus Trans Studio Bali CT Corp. Namun, jika menunjukkan ciri tidak baik, penelitian dijadikan evaluasi bagi perusahaan. Lebih lanjut, kerangka pemikiran dapat dilihat pada Gambar 3.

\section{HASIL}

\section{Gambaran Umum Perusahaan}

Trans Studio Bali merupakan theme park terbaru yang didirikan CT Corp melalui anak usahanya PT. Alfa Retailindo. Diresmikan Desember 2019, efektif beroperasi pada Januari 2020. Latar belakang pendirian usaha ini yakni aktivitas dari wisatawan di Bali yang sangat menjanjikan. Perusahaan juga menilai rekam jejak keberhasilannya mendirikan usaha sejenis di beberapa kota sebelumnya, dijadikan acuan mendirikan theme park ini. Unit ini diharapkan menjadi komplementari unit di Bali dan mendukung unit lainnya milik perusahaan.

Penawaran harga yang diberikan perusahaan dibedakan berdasarkan kebangsaan. Untuk pengunjung dalam negeri, harga yang ditawarkan Rp375.000 per individu. Sementara untuk pengunjung berkebangsaan luar, harga yang ditawarkan Rp600.000 per individu. Perusahaan menargetkan pasarnya terbagi atas Free Individual Traveler (FIT), dan Group Traveler (Non-FIT). Secara khusus, perusahaan lebih mengedepankan Non-FIT sebagai targetnya melalui kerjasama dengan pihak terkait seperti travel agency dan lainnya. Namun, pada Maret 2020, pandemi Covid-19 menyebar di Indonesia membuat aktivitas bisnis Trans Studio Bali terganggu. Dikarenakan peraturan terkait hal ini, mengakibatkan Trans Studio Bali yang baru efektif beroperasi selama tiga bulan harus menunda sementara aktivitasnya sejak 22 Maret 2020 sampai waktu yang belum ditentukan hingga tulisan ini dibuat.

\section{Penerapan Blue Ocean Strategy (BOS)}

Pendirian jaringan taman bermain Trans Studio dilakukan CT Corp sejatinya memang berangkat dari pemikiran untuk keluar dari status quo berdasarkan Blue Ocean Strategy (BOS). Dimana status quo harus menciptakan strategi masa depan yang gemilang, menerapkan penjauhan dari kompetisi (Kim \& Mauborgne, 2005). Hal ini diwujudkan CT Corp dengan inovasi nilai tawarannya yang menjadi pembeda dari pemain sejenis di industrinya, termasuk pada Trans Studio Bali. Inovasi ini tentu disesuaikan dengan pola pasar Trans Studio Bali, dengan merekonstruksi batasan pasar dan menjangkau melampaui permintaan, yang juga disesuaikan dengan kondisi perusahaan. Lebih lanjut, penerapan BOS pada Trans Studio Bali yakni sebagai berikut:

Inovasi Nilai

Wahana yang ditawarkan oleh perusahaan meliputi lima zona bermain yaitu Action Zone, Camera Zone, Culture Zone, Port of Liverpool, dan Adventure Zone. Beberapa wahana di Trans Studio Bali dapat ditemukan di beberapa tempat lain namun dengan konsep berbeda. Konsep ini menjadi signature produk perusahaan, meliputi digital video mapping, flying theater, dan ampid theather show. Wahana-wahana tersebut menggabungkan teknologi digital dari Jepang dengan mengadaptasi dan menonjolkan budaya lokal Indonesia terkhusus Bali yang menjadi daya tarik pasar. Hal ini terbilang langka sebab hanya terdapat depalan wahana sejenis di dunia. Konsep wahana dan inovasi nilai perusahaan berangkat dari pemikiran produk sentris menyuguhkan yang terbaik sekalipun mengharuskan mengimpor teknologi pendukung. Perusahaan melakukan survei melalui tim $R \& D$ terhadap penawaran nilai yang disuguhkan theme park di seluruh Indonesia dan theme park terkenal dunia. Meskipun demikian, perusahaan tetap memperhatikan capaian biaya sasaran dalam menyuguhkan inovasi nilai dengan memperhatikan corporate's organizational DNA. Organizational DNA adalah istilah metafora yang menunjukkan faktor fundamental yang menentukan karakter organisasi dan membantu menjelaskan kinerjanya (David dalam Nafei, 2014). Dalam hal ini, perusahaan melakukannya dengan menekankan pada pendapatan, menjaga pengeluaran se-minimum mungkin, agar menghasilkan margin tinggi. 


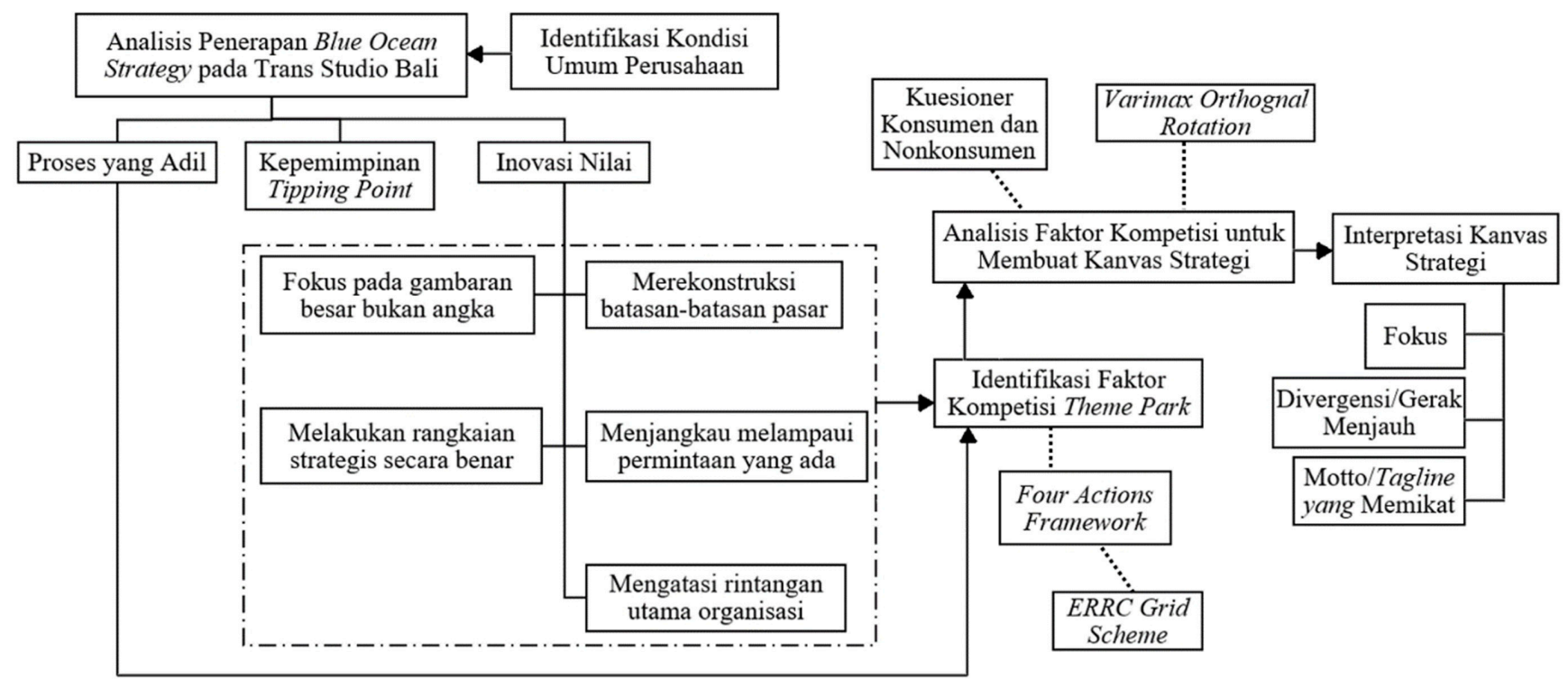

Gambar 3. Kerangka pemikiran penelitian

\section{Merekonstruksi Batasan Pasar}

Dalam merekonstruksi batasan pasar, perusahaan membagi konsumennya meliputi FIT, dan Non-FIT. Perusahaan mencermati pola pengambilan keputusan kedua kategori ini cenderung terhadap tujuan utama berkunjung dengan pertimbangan fasilitas pendukung segala usia, kemudahan akses dengan jarak penginapan, serta harga yang ditawarkan. Perusahaan juga mencermati penawaran produk dan jasa pelengkap secara terperinci baik di luar maupun di dalam Trans Studio Bali, seperti halnya fasilitas keamanan dan kenyamanan bagi infant bayi hingga lansia termasuk pembelian popok, fisilitas kursi roda, juga ruang tenang jika dirasa memberikan efek berarti secara psikis setelah dari wahana permainan yang didukung tenaga ahli terkait. Lebih lanjut, perusahaan secara terperinci menerapkan prosedur seperti body checking, pelaporan penyakit bawaan dan lainnya, baik sebelum maupun setelah dari wahana permainan untuk mengantisipasi kondisi tertentu demi keamanan dan kenyamanan pengunjung. Dalam hal mencermati industri alternatif, perusahaan menekankan pada upaya mewujudkan diferensiasi produk dimana untuk saat ini, industri alternatif yang tersedia bersifat partial experiences dan mengharuskan pengunjung membayar lebih setiap wahananya. Sementara, perusahaan menawarkan complete package didukung dengan komplementari unit lainnya dari CT Corp seperti hotel dan perbelanjaan ritel di Bali. Dalam mengatasi industri alternatif, perusahaan mengedepankan pemantauan pola kerjasama strategis yang diterapkan industri terhadap travel agency. Perusahaan berpedoman pada studi yang sebelumnya dilakukan terkait rasio rata-rata kedatangan untuk Trans Studio Bandung yang menjadi unit theme park acuannya, menunjukkan angka 2,2 per tahun. Artinya, satu pengunjung cenderung mengunjungi theme park yang sama dalam setahun maksimal dua kali. Karena itu, pola kerjasama strategis dianggap tepat menjangkau pengunjung baru didukung data historis tourist traffic di Bali yang merupakan pengunjung baru setiap harinya. Selain itu, terdapat tindakan strategis turunan yang dicermati perusahaan yaitu daily promotion, daily show, special events dengan guest star tertentu, serta annual membership yang beracuan pada lima tahapan rantai pembeli yang dicermati secara rutin serta disesuaikan dengan tren yang terjadi. Namun, khusus untuk kondisi Covid-19 yang tidak terduga, perusahaan tidak melakukan antisipasi sama sekali dimana untuk saat ini tindakan yang dilakukan adalah freezing aktivitas unit Trans Studio Bali sementara waktu sesuai dengan himbauan pemerintah setempat mengenai izin operasi. Tindakan ini juga meliputi keputusan merumahkan karyawan unit baik back office maupun service encounter.

\section{Fokus pada Gambaran Besar}

Perusahaan secara rutin mencermati tren eksternal yang terjadi dan menyatukan pemikiran internal manajemen untuk menerapkan strategi seperti apa berdasarkan tren tersebut. Hal ini juga didukung dengan upaya mencermati kondisi lapangan melalui tim $\mathrm{R} \& \mathrm{D}$ yang ditugaskan melihat produk, servis, serta model bisnis theme park di seluruh Indonesia dan theme park terkenal dunia, untuk selanjutnya dijadikan referensi dalam perumusan strategi. Perusahaan juga melakukan feasibility study berupa table top dengan pelaku usaha di Bali, terutama terkait 
umpan balik bagaimana perusahaan dapat bersinergi dengan travel agency dan usaha terkait lainnya dimana dapat menentukan model bisnis yang sesuai agar terjadi kerjasama saling menguntungkan. Selain itu, perusahaan melakukan penelitian terhadap konsumen dan nonkonsumen lokal maupun asing, melalui mini focus group discussion dan in-depth interview untuk mendapatkan umpan balik terkait harga dan tawaran produk. Strategi yang sudah dirumuskan manajemen perusahaan mendapatkan umpan balik dari jajaran eksekutif perusahaan melalui komunikasi secara visual yang selanjutnya digunakan untuk merumuskan strategi terbaik di masa depan. Dalam hal ini dapat dicermati bahwa seluruh perumusan dan keputusan strategis untuk unit Trans Studio Bali berpusat di headquarter dengan pendekatantop down. Hal ini tentunya tidak menunjukkan penerapan indikator komunikasi visual pada dimensi fokus pada gambaran besar sesuai teori yang merujuk pada keterlibatan karyawan dalam mengomunikasikan strategi dari top level hingga front line management.

\section{Menjangkau Melampaui Permintaan}

Perusahaan dalam hal ini cukup mencermati tiga tingkatan nonkonsumen namun tidak terlalu menaruh perhatian penuh terhadap calon nonkonsumen yang berada pada target pasar namun siap berpindah, nonkonsumen yang secara sadar memilih berada di luar pasar, serta nonkonsumen yang belum dijajaki dan terletak jauh dari pasar. Perusahaan berpedoman dengan studi terkait, bahwa pendekatan yang dilakukan theme park secara normatif bukanlah customer retention melainkan menjangkau pengunjung baru setiap harinya. Hal ini menjadi pertimbangan perusahaan dalam pemilihan lokasi Bali yang mana tourist traffic-nya merupakan pengunjung baru setiap harinya. Perusahaan untuk saat ini cenderung menekankan membangun awareness kepada seluruh pasar yang ada untuk selanjutnya dipelajari terkait pasar yang paling memberikan kontribusi.

\section{Rangkaian Strategis Secara Benar}

Dalam penerapan rangkaian strategis secara benar, perusahaan sudah menerapkannya sesuai dengan pertimbangan utilitas bagi konsumen, harga yang ditawarkan, penekanan terhadap capaian biaya yang digunakan, serta penangan hambatan pengadopsian. Perusahaan melakukannya melalui penelitian terhadap konsumen dan nonkonsumen lokal maupun asing, terkait utilitas produk, serta harga yang rela dibayarkan untuk produk bersifat kombinasi partial experiences.
Hal ini juga disinkronisasikan dengan corporate's organizational DNA terkait capaian biaya. Sementara untuk hambatan pengadopsian, saat ini belum terdapat hambatan strategis yang berarti. Namun, untuk hambatan teknis tentunya ada kemungkinan besar terjadi, terlebih dalam penggunaan teknologi. Upaya yang dilakukan perusahaan yakni daily monitoring agar mencapai zero failure. Terkhusus untuk kondisi Pandemi Covid-19, tindakan yang dilakukan adalah penundaan sementara aktivitas bisnis (freezing) dengan berbagai pertimbangan perizinan, struktur biaya, serta jangkauan pasar.

\section{Mengatasi Rintangan Utama Organisasi}

Keberhasilan usaha suatu perusahaan akan bergantung pada lingkungan internal dan eksternalnya (Sarah et al. 2019). Dalam teori blue ocean strategy menurut Kim \& Mauborgne (2005), terdapat empat rintangan utama organisasi: rintangan kognitif, rintangan sumber daya, rintangan motivasional, dan rintangan politik. Perusahaan sudah mencermati dan mengantisipasi keempat rintangan tersebut melalui HR Business Partner. Namun, untuk saat ini dikarenakan kondisi Pandemi Covid-19 yang mempengaruhi kegiatan bisnis Trans Studio Bali, terbilang belum dapat diterapkan mengingat kegiatan bisnis baru efektif berlangsung selama tiga bulan. Namun, secara keseluruhan terutama perihal rintangan sumber daya manusia sudah direncanakan untuk unit Trans Studo Bali. Perusahaan cenderung akan melakukan replacing dibandingkan empowering karyawan guna memastikan suguhan layanan perusahaan selalu fresh terkhusus untuk karyawan service encounter. Komposisi karyawan service encounter yang bersifat daily workers pada unit ini lebih banyak dibandingkan karyawan back office, sehingga upaya dalam memelihara motivasi karyawan disini lebih kepada memberikan tantangan baru untuk diraih. Sementara, untuk rintangan politik pada unit ini baik internal maupun eksternal, perusahaan tidak memandang hal ini sebagai hal mayoritas yang berarti dikarenakan pendekatan dengan stakeholder terkait dirasa cukup baik serta mendapat respon baik pula dimana perusahaan dipandang turut berkontribusi membangun iklim pariwisata daerah tersebut.

\section{Eksekusi Strategi dengan Proses yang Adil}

Proses yang adil dalam teori blue ocean strategy menurut Kim \& Mauborgne (2005) terdiri atas tiga elemen yang melibatkan keseluruhan karyawan yakni, engagement, explanation, dan expectation clarity. Perusahaan hanya menerapkan expectation clarity berupa kejelasan 
harapan target keluaran atas penerapan strategi. Sebab, pendekatan yang dilakukan perusahaan merupakan top down dimana elemen engagement dan explanation meliputi keterlibatan merumuskan dan penjelasan mengapa strategi tersebut dirumuskan hanya terjadi di top level management, serta middle dan lower level management berperan sebagai eksekutor untuk hal bersifat harian dan teknikal lainnya.

\section{Pemenuhan Ciri Blue Ocean Strategy (BOS) yang Baik}

Konsep kunci BOS mencakup inovasi nilai, kepemimpinan tipping point, dan eksekusi dengan proses yang adil. Perusahaan sudah dengan jelas dan terperinci menerapkan inovasi nilai pada unit Trans Studio Bali, serta menerapkan kepemimpinan tipping point dengan berfokus pada sentralisasi ide dan bukan desntralisasi untuk mengurangi tindakan tidak proposional melalui perumusan strategi pendekatan top down. Namun, untuk eksekusi dengan proses yang adil, perusahaan tidak dapat menerapkannya terkhusus kepada karyawan unit mencakup front line management yang bersifat daily workers.
Adapun tiga ciri BOS yang baik menurut Kim \& Mauborgne (2005) yaitu fokus, divergensi atau gerak menjauh, dan mempunyai motto/tagline memikat yang berbicara kepada pasar, dapat ditentukan dengan melihat kurva nilai pada kanvas strategi atas faktor-faktor kompetisi industri. Berkaitan dengan faktor-faktor kompetisi, kerangka kerja Four Actions Framework dan ERRC Grid Scheme dapat digunakan untuk mengidentifikasinya serta dikembangkan untuk merekonstruksi elemen-elemen nilai pembeli dalam membuat kurva nilai baru. Kerangka kerja tersebut mencakup empat pertanyaan kunci terkait faktor apa yang perlu dihapuskan, dikurangi, ditingkatkan, dan diciptakan.

Untuk saat ini, manajemen belum dapat menjawab empat pertanyaan kunci tersebut mempertimbangkan learning curve unit di Bali masih belum sempurna karena baru efektif beroperasi tiga bulan, sehingga dikhawatirkan strategi yang ada menjadi premature dalam membentuk kurva nilai baru. Dengan mempertimbangkan hal tersebut, untuk melihat pemenuhan ciri BOS yang baik pada Trans Studio Bali dalam penelitian ini, didasarkan pada kurva nilai saat ini. Identifikasi faktor-faktor kompetisi industri diperoleh melalui brainstorming peneliti dalam membandingkan penelitian-penelitian terdahulu pada Tabel 2.

Tabel 2. Identifikasi faktor-faktor kompetisi dalam Industri Theme Park

\begin{tabular}{|c|c|c|}
\hline Faktor & Simbol & Literatur \\
\hline Harga tiket & $\mathrm{H}$ & Lo \& Leung (2015), Domenech (2011), \\
\hline Motto/tagline menarik & M & Kim \& Mauborgne (2005) \\
\hline $\begin{array}{l}\text { Fasilitas tambahan seperti restoran, toilet, penginapan, } \\
\text { dll. }\end{array}$ & $\mathrm{P}$ & Domenech (2011) \\
\hline $\begin{array}{l}\text { Kondisi lingkungan dan ketergantungan dengan kondisi } \\
\text { cuaca dalam beroperasi }\end{array}$ & $\mathrm{L}$ & $\begin{array}{l}\text { Wei (2014), Lo \& Leung (2015), Pikkemaat \& } \\
\text { Schuckert (2007), Domenech (2011) }\end{array}$ \\
\hline $\begin{array}{l}\text { Desain dengan menonjolkan budaya lokal dan fasilitas } \\
\text { dengan esensi budaya lokal }\end{array}$ & $\mathrm{B}$ & Wei Guo (2014) \\
\hline Interaktivitas dan pertunjukan (show) yang disuguhkan & I & Pikkemaat \& Schuckert (2007), Domenech (2011) \\
\hline $\begin{array}{l}\text { Citra merek, presepsi, dan kegiatan pemasaran yang } \\
\text { dilakukan }\end{array}$ & $\mathrm{C}$ & $\begin{array}{l}\text { Pikkemaat \& Schuckert (2007), Lo \& Leung (2015), } \\
\text { Domenech (2011) }\end{array}$ \\
\hline Ukuran theme park, kapasitas dan manajemen antrian & $\mathrm{U}$ & $\begin{array}{l}\text { Pikkemaat \& Schuckert (2007), Wei (2014), } \\
\text { Domenech (2011) }\end{array}$ \\
\hline Keselamatan dan keamanan fasilitas & $\mathrm{K}$ & Pikkemaat \& Schuckert (2007), Lo \& Leung (2015) \\
\hline Desain theme park dan ragam macam atraksi & $\mathrm{D}$ & $\begin{array}{l}\text { Pikkemaat \& Schuckert (2007), Lo \& Leung (2015), } \\
\text { Wei Guo (2014), }\end{array}$ \\
\hline Pembangunan kota dan aksesibilitas menuju theme park & A & Pikkemaat \& Schuckert (2007), Wei (2014), \\
\hline
\end{tabular}


Faktor-faktor teridentifikasi tersebut diuji kepada 37 responden meliputi konsumen dan nonkonsumen Trans Studio Bali melalui kuesioner. Skala yang digunakan yakni skala ordinal menggunakan enam skor untuk menghindari ketidakpastian responden atau central tendency yaitu kecenderungan memilih jawaban tengah atau kategori cukup atau netral. Peneliti menggunakan nilai berinterval 1 sampai dengan 6 , dimana nilai 1 merupakan penilaian sangat tidak sesuai, sementara nilai 6 menunjukkan jawab sangat sesuai. Nilai rataan setiap faktor kompetisi tertuang pada Tabel 3.

Nilai rataan tersebut untuk menentukan skor pada sumbu vertikal kanvas strategi. Sedangkan untuk menentukan letak faktor kompetisi pada sumbu horizontal, digunakan dasar komponen utama berdasarkan analisis faktor yang telah dilakukan berdasarkan hasil Rotated Component Matrix. Pengolahan data menggunakan analisis faktor metode ekstraksi komponen utama (principal component). Pengelompokkan faktor kompetisi ke dalam komponen utama dilihat dari nilai loading yang dipilih berdasarkan angka mutlak terbesar. Berdasarkan tabel di atas, nilai loading yang diperoleh dari hasil varimax orthogonal rotation yang dilakukan terhadap
11 faktor kompetisi menghasilkan 2 komponen utama (Tabel 4). Adapun 2 komponen utama tersebut tertuang dalam sumbu horizontal kanvas strategi (Gambar 5).

Faktor kompetisi industri theme park Bali dibagi menjadi dua komponen utama sesuai Tabel 5. Dua komponen utama tersebut menjadi dasar pemetaan sumbu horizontal kanvas strategi. Sehingga, faktor kompetisi diurutkan berdasarkan komponen utama yang dikelompokkan dan ditempatkan berdekatan. Komponen utama pertama faktor kompetisi dapat digeneralisasikan sebagai faktor keunggulan produk bagi konsumen dan nonkonsumen. Faktor-faktor tersebut dinilai sebagai komponen utama dalam mempertimbangkan theme park di Bali, dengan citra merek, desain, interaktivitas, ukuran, keselamatan, aksesibilitas, budaya, fasilitas pelengkap, motto, dan operasional theme park berdasar kondisi lingkungan menjadi keunggulan produk yang paling dirasakan pasar. Sedangkan harga tiket merupakan komponen utama kedua yang dapat digeneralisasikan sebagai faktor yang kurang dipertimbangkan pasar sebagai keunggulan produk theme park.

Tabel 3. Rataan nilai kinerja faktor kompeitisi industri Theme Park di Bali

\begin{tabular}{lccccccccccc}
\hline Merek Theme Park & $\mathrm{H}$ & $\mathrm{M}$ & $\mathrm{P}$ & $\mathrm{L}$ & $\mathrm{B}$ & $\mathrm{I}$ & $\mathrm{C}$ & $\mathrm{U}$ & $\mathrm{K}$ & $\mathrm{D}$ & $\mathrm{A}$ \\
\hline Theme park terkenal & 4,43 & 5,05 & 4,70 & 1,74 & 4,11 & 4,46 & 4,62 & 4,78 & 5,05 & 4,84 & 4,72 \\
Trans Studio Bali & 4,05 & 5,24 & 5,00 & 3,22 & 4,78 & 5,11 & 5,30 & 5,35 & 5,51 & 5,65 & 5,78 \\
Theme park lainnya & 4,28 & 4,51 & 4,78 & 1,85 & 3,92 & 4,50 & 4,71 & 4,86 & 5,1 & 4,73 & 4,84 \\
\hline
\end{tabular}

Tabel 4. Asosiasi faktor kompetisi industri Theme Park di Bali

\begin{tabular}{lcccccccccccc}
\hline Component & $\mathrm{H}$ & $\mathrm{M}$ & $\mathrm{P}$ & $\mathrm{L}$ & $\mathrm{B}$ & $\mathrm{I}$ & $\mathrm{C}$ & $\mathrm{U}$ & $\mathrm{K}$ & $\mathrm{D}$ & $\mathrm{A}$ \\
\hline 1 & 0,271 & 0,637 & 0,721 & 0,613 & 0,649 & 0,771 & 0,792 & 0,847 & 0,711 & 0,809 & 0,158 \\
2 & 0,81 & 0,215 & 0,149 & 0,126 & 0,10 & 0,043 & 0,001 & $-0,043$ & $-0,059$ & $-0,132$ & $-0,84$ \\
\hline
\end{tabular}

Tabel 5. Komponen utama berdasarkan nilai loading faktor kompetisi

\begin{tabular}{lccccccccccc}
\hline \multicolumn{11}{c}{ Komponen Pertama } \\
\hline $\mathrm{C}$ & $\mathrm{D}$ & $\mathrm{I}$ & $\mathrm{U}$ & $\mathrm{K}$ & $\mathrm{A}$ & $\mathrm{B}$ & $\mathrm{P}$ & $\mathrm{M}$ & $\mathrm{L}$ & Komponen Kedua \\
\hline 0,847 & 0,809 & 0,792 & 0,771 & 0,721 & 0,711 & 0,649 & 0,637 & 0,613 & 0,158 & $\mathrm{H}$ & 0,81 \\
\hline
\end{tabular}




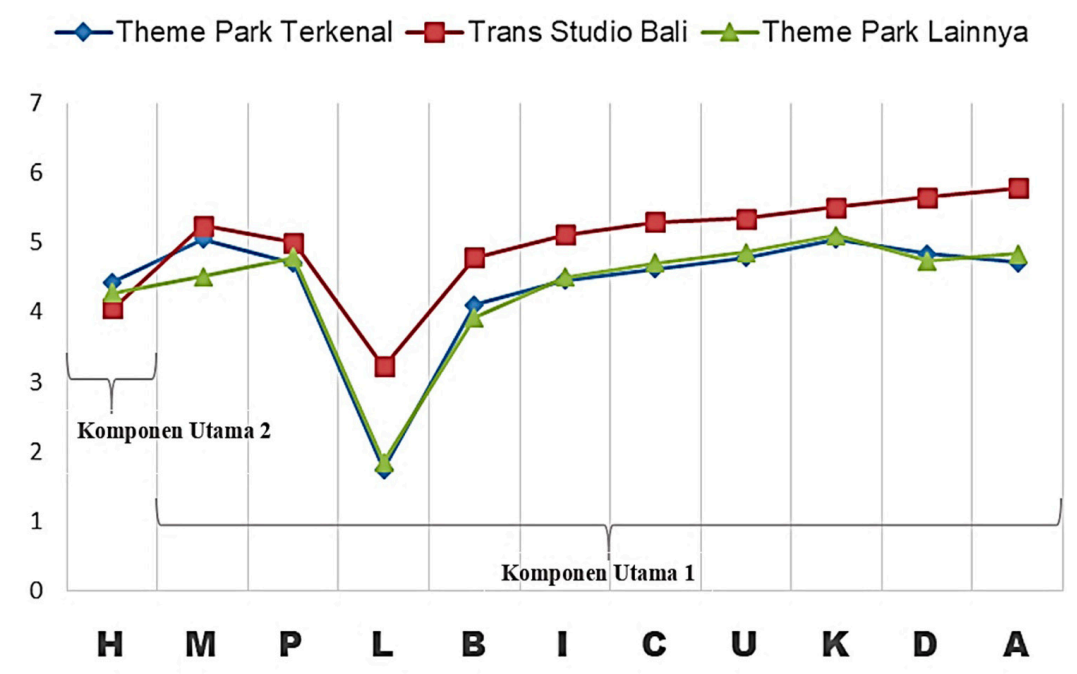

Gambar 4. Kanvas Strategi Industri Theme Park Bali

Kim \& Mauborgne (2005) menjelaskan tentang interpretasi kurva nilai pada kanvas strategi yang menunjukkan ciri baik, yaitu Fokus, perusahaan tidak menyebarkan usahanya ke semua faktor utama dalam kompetisi; Divergensi, menjauh dari pemain-pemain lain, sebuah hasil dari mencari dan melihat alternatif dan bukan membanding-bandingkan dengan pemain atau pesaing lain; Motto/tagline yang memikat. Kurva nilai Trans Studio Bali pada industri theme park di Bali dapat terinterpretasi menunjukkan posisi perusahaan yang berada pada kondisi blue ocean dan tidak terperangkap dalam red ocean, tercermin pada faktor-faktor kompetisi perusahaan bernilai tinggi. Perusahaan memilki motto yang memikat dibandingkan pemain-pemain lain dalam industrinya yakni "The Most Instagramable Theme Park in The World" ditunjukkan dari penilaian responden, serta kurva nilai perusahaan menunjukkan divergensi bergerak menjauh dari kompetisi industri. Meski demikian, penerapan BOS pada Trans Studio Bali tetap tidak dapat memenuhi ciri BOS yang baik. Hal ini karena kurva nilai perusahaan menunjukkan nilai tinggi pada keseluruhan faktor kompetisi utama 1. Sementara, ciri kurva nilai BOS yang baik yakni berfokus pada faktor kompetisi unggulan dan tidak menyebarkan ke semua faktor utama kompetisi.

Penelitian terdahulu oleh Mohammad Ali Al Qudah, Tareq N. Hashem (2018) yang berjudul "The Impact of Applying the Blue Ocean Strategy on the Achievement of a Competitive Advantage: A Field Study Conducted in The Jordanian Telecommunication Companies." mengidentifikasi dampak penerapan BOS terhadap pencapaian keunggulan kompetitif menunjukkan bahwa proses eliminasi, proses reduksi, peningkatan proses, dan inovasi, yang mana secara keseluruhan merupakan dimensi pada BOS, secara signifikan mempengaruhi pencapaian keunggulan kompetitif. Namun pada penelitian ini, pengaruhnya pada keunggulan kompetitif nampak memposisikan perusahaan, dalam hal ini Trans Studio Bali, berada pada titik tinggi di keseluruhan faktor kompetisi utama kecuali harga tawaran. Yulianto et al. (2020) mengemukakan, faktor-faktor yang memengaruhi nilai perusahaan antara lain: profitabilitas, umur perusahaan, financial leverage, dan kebijakan dividen. Sehingga, dapat tercermin bahwa kurva nilai perusahaan atas penerapan BOS pada Trans Studio Bali menimbulkan pertanyaan lanjutan apakah pangsa pasar dan profitabilitas perusahaan mencerminkan investasi.

\section{Implikasi Manajerial}

Perusahaan diharapkan dapat memperhatikan lebih lanjut evaluasi penawaran nilai pada produk untuk unit Trans Studio Bali. Hal ini mempertimbangkan kurva nilai menunjukkan penilaian tinggi terhadap produk perusahaan di hampir seluruh faktor kompetisi utama industri. Evaluasi ini disesuaikan dengan pangsa pasar utama untuk melihat profitabilitas perusahaan dan cerminan investasinya. Perusahaan diharapkan dapat memperhatikan dan menyesuaikan kondisi dengan cepat terkhusus saat pandemi Covid-19. Penyesuaian yang diharapkan terkait prosedur operasi yang beracuan dengan penerapan protokol kesehatan untuk selanjutkan mengomunikasikannya dengan stakeholder terkait agar selanjutnya memperoleh izin operasi. 


\section{KESIMPULAN DAN SARAN}

\section{Kesimpulan}

Berdasarkan temuan penelitian yang sudah dijelaskan, dapat disimpulkan penerapan Blue Ocean Strategy (BOS) pada Trans Studio Bali tidak sepenuhnya menerapkan tiga konsep kunci BOS dan tidak juga memenuhi tiga ciri BOS yang baik berdasarkan teori Kim \& Mauborgne (2005). Dimana penyebab yang menjadikan penerapan BOS pada Trans Studio Bali tidak termasuk BOS yang baik, dapat dipengaruhi oleh beberapa hal, yakni Indikator pada konsep kunci BOS yang tidak dapat diterapkan perusahaan, dimana melibatkan karyawan dari top level hingga front line management; Interpretasi kurva nilai perusahaan yang menunjukkan nilai tinggi di seluruh faktor-faktor kompetisi industri kecuali harga yang ditawarkan. Hal ini mengindikasikan bahwa penawaran nilai yang diberikan perusahaan tinggi namun harga terkait produknya dinilai pasar masih terlampau tinggi dari pemain lain di industri yang sama. Dengan kata lain, harga yang ditawarkan tidak menunjukkan keunggulan; Meskipun manajemen perusahaan secara sadar mengatakan memperhatikan dengan seksama capaian biaya pada corporate's organizational DNA, interpretasi kurva nilai perusahaan pada kanvas startegi tetap menimbulkan pertanyaan lanjutan apakah pangsa pasar dan profitabilitas perusahaan mencerminkan investasi. Jika tidak, ada kemungkinan perusahaan memberikan pasokan berlebih, dimana memberikan penawaran terlalu banyak kepada konsumennya.

\section{Saran}

Hasil penelitian dapat dijadikan ide pengembangan penelitian kedepan. Perluasan penelitian yang disarankan adalah meneliti lebih lanjut apakah pangsa pasar dan profitabilitas perusahaan mencerminkan investasi atau perusahaan justru menyuguhkan pasokan berlebih dalam penawaran produk. Selain itu, diperlukan penelitian lebih lanjut mengenai hal lain yang berpotensi menjadi penyebab penerapan BOS pada perusahaan tidak memenuhi ciri yang baik.

Penelitian ini dibatasi pada ruang lingkup bahasan yang berfokus pada penerapan Blue Ocean Strategy (BOS) pada Trans Studio Bali PT. Chairul Tanjung Corpora. Terdapat hal lainnya dalam interpretasi kurva nilai perusahaan pada kanvas strategi, dimana membutuhkan data internal pendukung mengenai besaran cerminan investasi produk dan pangsa pasar terkait, dan halhal lainnya yang cukup confidential bagi perusahaan. Implementasi implikasi manajerial dari penelitian ini diserahkan kembali kepada PT. Chairul Tanjung Corpora sepenuhnya.

\section{DAFTAR PUSTAKA}

Aithal PS. 2016. The concept of ideal strategy and its realization using white ocean mixed strategy. International Journal of Management Sciences and Business Research 5(4): 171-179.

[BPKM] Badan Koordinasi Penanaman Modal. 2018. Realisasi Investasi Pariwisata Capai Rp 7,9 Triliun di Semester I 2018. https://www. bkpm.go.id/id/publikasi/detail/berita/realisasiinvestasi-pariwisata-capai-rp-79-triliun-disemester-i-2018. [10 Mar 2020].

[IFC] International Finance Corporation. 2019. IFC Supports Green Retail, Tourism, and Property Projects in Indonesia with $\$ 275$ Million Loan to Trans Corp. https://ifcextapps.ifc. org/IFCExt/Pressroom/IFCPressRoom.nsf/0/ E9151FC2DD2BF61D852583A600072C24. [17 Jul 2020].

[Kemenpar] Kementerian Pariwisata. 2019. Rencana Strategis Kementerian Pariwisata 2018-2019 Revisi 4. http://eperformance.kemenpar.go.id/ dokumen/3Buku\%20RENSTRA\%2020182019_Revisi\%204_opt.pdf. [10 Mar 2020].

Alwi I. 2012. Kriteria empirik dalam menentukan ukuran sampel pada pengujian hipotesis statistika dan analisis butir. Jurnal Formatif 2(2): 140-148. http://dx.doi.org/10.30998/formatif.v2i2.95.

Astuti WP, Kusumawati A. 2018. Upaya pemasaran pariwisata ponorogo melalui city branding dalam meningkatkan kunjungan wisatawan. Jurnal Administrasi Bisnis 55(1): 48-58.

Burke AE, Van Stel AJ, Thurik R. 2009. Blue Ocean Versus Competitive Strategy: Theory and Evidence. ERIM Report Series Reference No. ERS-2009-030-ORG.

Catriana E, Jatmiko BP. 2020. Kemenparekraf: Realisasi Investasi di Sektor Pariwisata Kuartal I-2020 401,4 Juta Dollar AS. Kompas.com. https://money. kompas.com/read/2020/08/05/155422226/ kemenparekrafrealisasi-investasi-di-sektorpariwisata-kuartal-i-2020-4014. [30 Oktober 2020]. 
Damayanthi PDA. 2016. Pengaruh idealisme, relativisme, pengetahuan, gender dan umur pada perilaku tidak etis akuntan. E-Jurnal Akuntansi Universitas Udayana 15(1): 1-16.

Databoks. 2019. Realisasi Investasi Sektor Pariwisata CapaiRp20,9 Triliun pada 2018. https://databoks. katadata.co.id/datapublish/2019/07/12/realisasiinvestasisektor-pariwisata-capai-rp-209-triliunpada-2018. [30 Okt 2020].

Domenech J. 2011. Determining Factors of Theme Park Attendance [tesis]. Colorado Springs: The Faculty of the Department of Economics and Business, The Colorado College.

Fajarin I. 2020. Analisis daya saing sektor pariwisata kabupaten banyuwangi: pendekatan competitiveness monitor dan porter's diamond. Jurnal Ilmiah Mahasiswa FEB 8(2).

Guo W. 2014. What affects theme park performance: a comparative case study of disney theme parks in East Asia. American Journal of Economics 5(5): 472-476. http://dx.doi.org/10.5923/j. economics.20150505.05.

Himayati, Switrayni NW, Komalasari D, Fitriyani N. 2020. Analisis rotasi ortogonal pada teknik analisis faktor menggunakan metode procrustes. Eigen Mathematics Journal 3(1): 45-55. https:// doi.org/10.29303/emj.v3i1.66.

Kim WC, Mauborgne R. 2009. Blue Ocean Strategy, Strategi Samudera Biru (Terjemahan), Cetakan kesepuluh. Jakarta: Serambi Ilmu Semesta. (Original Publisher: Harvard Business School Publishing Corporation. 2005).

Lo J, Leung P. 2015. The preferred theme park. American Journal of Economics 5(5): 472-476. https://doi.org/10.7916/d8xd18bq.

Nafei W. 2014. The role of organizational DNA in improving organizational performance: a study on the industrial companies in Egypt. International Business Research 8(1): 117-132. http://doi.org10.5539/ibr.v8n1p117.

Nurudin M, Mara MN, Kusnandar D. 2014. Ukuran sampel dan distribusi sampling dari beberapa variabel random kontinu. Buletin Ilmiah Mat. Stat. dan Terapannya (Bimaster) 3(1): 1-6. http:// dx.doi.org/10.26418/bbimst.v3i01.4461.
Pikkemaat B, Schuckert M. 2007. Success Factors of Theme Parks - An Exploratory Study. Tourism Preliminary Communication 55(2): 197-208.

Rahardjo B. 2013. Analisisfaktor untuk mengetahui pengaruh personal selling dan word of mouth terhadap keputusan pembelian suatu studi kasus pada PT. Starmas Inti Alumunium Industri. Jurnal Ekonomi dan Manajemen 2(1): 1-19.

Rawabdeh I, Raqab A, Al-Nimri D, Haddadine S. 2012. Blue ocean strategy as a tool for improving a company's marketing function: The case of Jordan. Jordan Journal of Business Administration 8(2): 390-407.

Sarah D, Suryana NR, Kirbrandoko. 2019. Strategi bersaing industri madu (Studi Kasus: CV Madu Apiari Mutiara). Jurnal Aplikasi Manajemen dan Bisnis 5(1): 71-83. http://dx.doi.org/10.17358/ jabm.5.1.71.

Simamora B. 2005. Analisis Multivarian Pemasaran. Jakarta: PT Gramedia Pustaka Utama.

Sitinjak MF, Pramawijaya K, Gunawan A. 2018. ICanStudioLive use of blue ocean marketing strategy for value differentiation. Pertanika Journal of Social Science and Humanities 26(T): $203-214$.

Southern M. 2020. Coronavirus And $T h e$ Impact On Businesses So Far - Who's Up \& Who's Down? https://www.searchenginejournal. com/coronavirus-and-the-impact-on-businessesso-far-whos-up-whos-down/357308/\#close. [11 Okt 2020].

The Jakarta Post. 2020. Bali Sees Almost 100 Percent Drop in Foreign Tourists. https://www. thejakartapost.com/travel/2020/04/25/bali-seesalmost-100-percent-drop-in-foreign-tourists . html. [11 Okt 2020].

Yulianto, Widyasasi. 2020. Analisis faktor-faktor yang mempengaruhi nilai perusahaan. Jurnal Paradigma Akuntansi 2(2): 576 - 585. http:// dx.doi.org/10.24912/jpa.v2i2.7622.

Zgheib PW. 2017. Entrepreneurship and Business Innovation in the Middle East. Lebanon: IGI Global. 